\title{
Sex differences in health and disease: brain and heart connections - a special issue
}

\author{
Jonggonnee Wattanapermpool • Pieter P. de Tombe • \\ Toni R. Pak
}

Received: 2 April 2013 / Accepted: 3 April 2013 / Published online: 16 April 2013

(C) Springer-Verlag Berlin Heidelberg 2013

The phenotypic manifestations of all physiological processes are routinely dictated by specific microenvironmental cues in the cell. As such, the well-recognized sex-based differences in many physiological responses and pathological outcomes should be in closed link to the unique role of sex steroid hormones, which ubiquitously target and freely enter all cell types in the body. Significantly, various impacts of the sex hormones, by both genomic and nongenomic actions, have been demonstrated in every level from gene expression to the whole intact animal models [3, $4,9,10,14,16,25]$. This special issue focuses particularly on the distinctive role of sex steroid hormones in two major organs, the brain and the heart, that are intimately connected, highly integrated, and often the major underlying mechanistic bases of most pathological conditions with emphasis on the issue of sex differences in health and disease. The articles compiled for this special issue were invited contributions from world leaders in their respective fields of research.

It has been more than a decade since the landmark clinical study on hormone replacement therapy in postmenopausal women has raised concerns about the many risks associated with the therapy [20]. The major concern was

\footnotetext{
J. Wattanapermpool

Department of Physiology, Faculty of Science,

Mahidol University, 277 Rama 6 Road, Rajthavee,

Bangkok 10400, Thailand

e-mail: jonggonnee.wat@mahidol.ac.th

P. P. de Tombe $(\varangle) \cdot$ T. R. Pak

Department of Cell and Molecular Physiology, Stritch School of Medicine, Loyola University Chicago, 2160 South First Ave, Maywood, IL 60153-5500, USA

e-mail: pdetombe@lumc.edu

T. R. Pak

e-mail: tpak@lumc.edu
}

the sharp increase in heart disease and death in the patients treated with a combined regimen of estrogen and progesterone. However, many studies in animal models have indicated the significant cardioprotective effects of both estrogen [5-7] and androgen $[9,25]$. Despite the hypothesized significant role in myocardial function, how these steroid sex hormones perform the tasks responsible for the different outcomes are not yet well understood. Thus, several reviews in this issue have covered the context of sex differences in electrical signal and electrocardiography [22], in mechanical induction by excitation-contraction coupling [19], and in the energetics and metabolism of the heart [26]. Sex differences in cardiac adaptations to differential stresses either physiological, like conditions of exercise-induced cardiac hypertrophy [12] and nonischemic myocardial remodeling [15], or pathological, like ischemia-reperfusion injury [17], have also been included. Lastly, overview contribution of estrogen and estrogen receptors in cardiovascular oxidative stress is reviewed [1].

Mental health disorders and associated substance abuse are often comorbid with heart disease. Thus, several manuscripts in this issue focus on sex differences in emotion and anxiety [11], cognition and learning [2], alcohol abuse/withdrawal [21], and depression in association with cardiovascular disease [23]. Sex differences connecting the brain and heart are reinforced in the manuscripts of Gonzales [13] and Wilson [24] who describe the effects of sex hormones on the cerebral vasculature and recovery after stroke/ischemic injury. Lastly, the molecular aspects of sex differences are explored, especially pertaining to neurodevelopment and the epigenetics of sex steroid hormone action [8]. In addition, Pak et al. [18] provide an overview of the newly emerging field of regulatory microRNAs, with emphases on neurodevelopment, puberty, aging, and potential brain-heart connections. Together, 
these neuro-focused reviews integrate what is known about sex steroid hormones on brain function, while drawing pertinent correlates and extending these findings to the more recent novel discoveries in the heart and vasculature.

\section{References}

1. Arias-Loza P-A, Muehlfelder M, Pelzer T (2013) Estrogen and estrogen receptors in cardiovascular oxidative stress. Pflügers Archiv Eur J Physiol. doi:10.1007/s00424-013-1247-7, This special issue

2. Auyeung B, Lombardo MV, Baron-Cohen S (2013) Prenatal and postnatal hormone effects on the human brain and cognition. Pflügers Archiv - European Journal of Physiology (in press). This special issue

3. Ayres S, Abplanalp W, Liu JH, Subbiah MT (1998) Mechanisms involved in the protective effect of estradiol-17beta on lipid peroxidation and DNA damage. Am J Physiol 274:E1002-1008

4. Babiker FA, De Windt LJ, van Eickels M, Thijssen V, Bronsaer RJ, Grohe C, van Bilsen M, Doevendans PA (2004) 17beta-estradiol antagonizes cardiomyocyte hypertrophy by autocrine/paracrine stimulation of a guanylyl cyclase A receptor-cyclic guanosine monophosphate-dependent protein kinase pathway. Circulation 109:269-276

5. Bupha-Intr T, Oo YW, Wattanapermpool J (2011) Increased myocardial stiffness with maintenance of length-dependent calcium activation by female sex hormones in diabetic rats. Am J Physiol Heart Circ Physiol 300:H1661-1668

6. Bupha-Intr T, Wattanapermpool J (2006) Regulatory role of ovarian sex hormones in calcium uptake activity of cardiac sarcoplasmic reticulum. Am J Physiol Heart Circ Physiol 291:H1101-1108

7. Bupha-Intr T, Wattanapermpool J, Pena JR, Wolska BM, Solaro RJ (2007) Myofilament response to $\mathrm{Ca}^{2+}$ and $\mathrm{Na}^{+} / \mathrm{H}^{+}$exchanger activity in sex hormone-related protection of cardiac myocytes from deactivation in hypercapnic acidosis. Am J Physiol Regul Integr Comp Physiol 292:R837-843

8. Chung WCJ, Auger AP (2013) Gender differences in neurodevelopment and epigenetics. Pflügers Archiv Eur J Physiol. doi:10.1007/s00424-013-1258-4, This special issue

9. Curl CL, Delbridge LM, Canny BJ, Wendt IR (2009) Testosterone modulates cardiomyocyte $\mathrm{Ca}^{2+}$ handling and contractile function. Physiol Res 58:293-297

10. Donaldson C, Eder S, Baker C, Aronovitz MJ, Weiss AD, HallPorter M, Wang F, Ackerman A, Karas RH, Molkentin JD, Patten RD (2009) Estrogen attenuates left ventricular and cardiomyocyte hypertrophy by an estrogen receptor-dependent pathway that increases calcineurin degradation. Circ Res 104:265-275

11. Donner NC, Lowry CA (2013) Sex differences in anxiety and emotional behavior. Pflügers Archiv - European Journal of Physiology (in press). This special issue

12. Foryst-Ludwig A, Kintscher U (2013) Sex differences in exerciseinduced cardiac hypertrophy. Pflügers Archiv - European Journal of Physiology (in press). This special issue
13. Gonzales RJ (2013) Androgens and the cerebrovasculature: modulation of vascular function during normal and pathophysiological conditions. Pflügers Archiv - European Journal of Physiology (in press). This special issue

14. Gurgen D, Hegner B, Kusch A, Catar R, Chaykovska L, Hoff U, Gross V, Slowinski T, da Costa Goncalves AC, Kintscher U, Gustafsson JA, Luft FC, Dragun D (2011) Estrogen receptor-beta signals left ventricular hypertrophy sex differences in normotensive deoxycorticosterone acetate-salt mice. Hypertension 57:648-654

15. Janicki JS, Spinale FG, Levick SP (2013) Gender differences in non-ischemic myocardial remodeling: are they due to estrogen modulation of cardiac mast cells and/or membrane type 1 matrix metalloproteinase. Pflügers Archiv Eur J Physiol. doi:10.1007/ s00424-013-1229-9, This special issue

16. Kararigas G, Fliegner D, Gustafsson JA, Regitz-Zagrosek V (2011) Role of the estrogen/estrogen-receptor-beta axis in the genomic response to pressure overload-induced hypertrophy. Physiol Genomics 43:438-446

17. Korzick DH, Lancaster TS (2013) Age-related differences in cardiac ischemia-reperfusion injury: effects of estrogen deficiency. Pflügers Archiv Eur J Physiol. doi:10.1007/s00424-013-1255-7, This special issue

18. Pak TR, Rao YS, Prins SA, Mott NN (2013) An emerging role of microRNAs in sexually dimorphic neurobiological systems. Pflügers Archiv Eur J Physiol. doi:10.1007/s00424-013-1227-y, This special issue

19. Parks RJ, Howlett SE (2013) Sex differences in mechanisms of cardiac excitation-contraction coupling. Pflügers Archiv Eur J Physiol. doi:10.1007/s00424-013-1233-0, This special issue

20. Rossouw JE, Anderson GL, Prentice RL, LaCroix AZ, Kooperberg C, Stefanick ML, Jackson RD, Beresford SA, Howard BV, Johnson KC, Kotchen JM, Ockene J (2002) Risks and benefits of estrogen plus progestin in healthy postmenopausal women: principal results from the Women's Health Initiative randomized controlled trial. JAMA 288:321-333

21. Sharrett-Field L, Reynolds AR, Berry JN, Prendergast MA (2013) Sex differences in neuroadaptation to alcohol and withdrawal neurotoxicity. Pflügers Archiv Eur J Physiol. doi:10.1007/ s00424-013-1266-4, This special issue

22. Smetana P, Malik M (2013) Sex differences in cardiac autonomic regulation and in repolarisation electrocardiography. Pflügers Archiv Eur J Physiol. doi:10.1007/s00424-013-1228-x, This special issue

23. Tobet S, Handa R, Goldstein JM (2013) Sex-dependent pathophysiology as predictors of comorbidity of major depressive disorder and cardiovascular disease. Pflügers Archiv Eur J Physiol. doi:10.1007/s00424-013-1248-6, This special issue

24. Wilson ME (2013) Stroke: understanding the differences between males and females. Pflügers Archiv Eur J Physiol, This special issue

25. Witayavanitkul N, Wowanush W, Bupha-Intr T, Wattanapermpool J (2013) Testosterone regulates cardiac contractile activation by modulating SERCA but not NCX activity. Am J Physiol Heart Circ Physiol 304:H465-H472

26. Wittnich C, Tan L, Wallen WJ, Belanger M (2013) Sex differences in myocardial metabolism and cardiac function: an emerging concept. Pflügers Archiv Eur J Physiol. doi:10.1007/s00424-013-1232-1, This special issue 